\title{
Soil Quality and Methods for its Assessment
}

\author{
Diego De la Rosa and Ramon Sobral
}

\begin{abstract}
Environmental sustainability will only be achieved by maintenance and improvement of soil quality. Soil quality is considered as the capacity of a soil to function. Its assessment focuses on dynamic aspects to evaluate the sustainability of soil management practices. In this chapter, a wide perspective of soil quality and the complex task of its assessment, considering the inherent and dynamic factors, are introduced. It focuses on the possibilities of applying and integrating the accumulated knowledge in agroecological land evaluation in order to predict soil quality. Advanced information technologies in modern decision support tools enable the integration of large and complex databases, models, tools, and techniques, and are proposed to improve the decision-making process in soil quality management. Although universal recommendations on soil quality and sustainability of soil management must not be done, this chapter presents general trends in soil quality management strategies. This includes arable land identification, crop diversification, organic matter restoration, tillage intensity, and soil input rationalization.
\end{abstract}

Keywords Agroecological land evaluation, dynamic soil quality, inherent soil quality, MicroLEIS, soil function, soil health, soil indicator, spatial decision support tool, sustainable agricultural system

\subsection{Introduction}

The results of exploiting land-use systems without consideration of the consequences on soil quality have been environmental degradation. Agricultural use and management systems have been generally adopted without recognizing consequences on soil conservation and environmental quality, and therefore significant decline in agricultural soil quality has occurred worldwide (e.g., Imeson et al., 2006). Soil erosion and diffuse soil contamination are the major degradation processes on agricultural lands as a consequence of expansion and intensification of agriculture. Other nonagricultural uses, such as industrial and urban uses, also have 
important negative consequences on soil quality, due to local contamination, soil sealing, and changes in the dynamics of the landscape systems (see Chapter 10).

The concept of soil quality (Doran \& Jones, 1996; Karlen et al., 1997) is useful to assess the condition and sustainability of soil and to guide soil research, planning, and conservation policy. However, some authors (e.g., Sojka \& Upchurch, 1999; who first introduced this controversy) consider the soil-quality paradigm as parochial, despite its application by several US institutions such as the Soil Quality Institute. Other workers such as Davidson (2000) noted that soil quality is a valid and important concept that is not amenable to a simple and universal definition, and that will make a distinctive and crucial contribution to soil management.

The importance of soil quality lies in achieving sustainable land use and management systems, to balance productivity and environmental protection. Unlike water and air quality, simple standards for individual soil-quality indicators do not appear to be sufficient because numerous interactions and trade-offs must be considered. For assessing soil quality a complex integration of static and dynamic chemical, physical, and biological factors need to be defined in order to identify different management and environmental scenarios. Also, the consequences of any decline in soil quality may not be immediately experienced. The soil system does not necessarily change as a result of changing external conditions or use, because soil has the capacity of resistance (or resilience) to the effects of potentially damaging conditions or misuse or to filter out harmful materials added to it. In part, this capacity of the soil in buffering the consequences of inputs and changes in external conditions arises because the soil is an exceedingly complex and varied material with many diverse properties and interactions between soil properties. It is this complex dynamic nature which often makes it difficult to distinguish between changes as a result of natural development and changes due to nonnatural external influences. Soil-quality assessment, based on inherent soil factors and focusing on dynamic aspects of soil system, is an effective method for evaluating the environmental sustainability of land use and management activities (Nortcliff, 2002).

However, the process of evaluating soil is not new, and agroecological land evaluation has much to offer. Land suitability is defined in land evaluation as "the fitness of a given land unit for a specified type of land use" (FAO, 1976). In a more operational sense, suitability expresses how well the biophysical potentialities and limitations of the land unit match the requirements of the land-use type. Therefore, new investigations must obviously be based on a solid understanding of past studies (De la Rosa, 2005). Agroecological land evaluation predicts land behavior for each particular use, and soil-quality evaluation predicts the natural ability of each soil to function. However, land evaluation is not the same as soil-quality assessment, because biological parameters of the soil are not considered in land evaluation. Soil surveys are the building blocks of the dataset needed to drive land evaluation. Soil surveys and soil taxonomy systems are used to define with precision specific soil types.

Emerging technologies in data and knowledge engineering are providing excellent possibilities for the development and application processes of soil-quality 
assessment. As in land evaluation, the application phase of soil-quality assessment is a complex process of scaling-up from the representative areas of the development phase to implementation in unknown scenarios. This application phase can be executed with computer-assisted procedures. It involves the development and linkage of integrated components, the recently named decision or planning support tools (e.g., MicroLEIS system; De la Rosa et al., 2004). Decision support systems are computerized technology that can be used to support complex decision-making and problem-solving. Technically, decision support system comprises components for (i) sophisticated database management capabilities with access to internal and external data, information, and knowledge, (ii) powerful modeling functions accessed by a model management system, and (iii) simple user interface designs that enable interactive queries, reporting, and graphing functions (e.g., Oxley et al., 2004).

As reported by the Soil Quality Institute (USDA, 2006), the ultimate purpose of assessing soil quality is not to achieve high aggregate stability, biological activity, or some other soil property. The purpose is to protect and improve long-term agricultural productivity, water quality, and habitats of all organisms including people. By assessing soil quality, a land manager will be able to determine if a set of management practices is sustainable. For example, agricultural management systems located on the most suitable lands, according to their agroecological potentialities and limitations, are the best way to achieve sustainability.

There is a need to investigate coordinated and multidisciplinary approaches to assessing soil quality, evaluating long-term potential and limitations (inherent soil aspects), and monitoring the short-term changes (dynamic soil aspects) in response to sustainable soil use and management. This chapter presents a wide perspective on soil quality and the complex task of its assessment, considering the inherent and dynamic aspects of soil system. It focuses on the possibilities for applying and integrating accumulated knowledge on land-evaluation modeling, in order to predict soil-quality indexes. Advanced information technologies, which enable the integration of large and complex databases, models, tools and techniques, are proposed to improve the decision-making process in soil-quality assessment application. Finally, general trends in soil-quality management strategies are discussed.

\subsection{Soil Quality}

As suggested in the early 1990s, soil quality is "the capacity of a soil to function". More specifically, soil quality has been defined by a committee for the Soil Science Society of America (Karlen et al., 1997) as "the capacity of a specific kind of soil to function, within natural or managed ecosystem boundaries, to sustain plant and animal productivity, maintain or enhance water and air quality, and support human health and habitation". Also, soil quality can be considered as the ability of a soil 
to fulfill its functions in the ecosystem, which are determined by the integrated actions of different soil properties. With respect to agriculture, soil quality would be the soil's fitness to support crop growth without becoming degraded or otherwise harming the environment.

Some authors (e.g. Warkentin, 1995) have suggested that soil quality is simply related to the quantity of crops produced. However, others have emphasized the importance of demonstrating how soil quality affects feed and food quality, or how soil quality affects the habitat provided for a wide array of biota. Numerous other aspects associated with the living and dynamic nature of soil will be encountered if the concept of soil quality is considered in relation to different land uses: forest and rangeland ecosystems, urban and industrial land, recreational uses, etc. Because of the diversity of potential land uses, the concept of soil quality should be viewed as relative rather than absolute. Therefore, each soil has a natural capacity to perform a specific function.

According to the Soil Quality Institute (USDA, 2006), the soil-quality concept is related to the concepts of sustainability of soil use and management, although in some cases the focus has been predominantly on contaminated land. To do that the notion of soil quality must include soil productivity, soil fertility, soil degradation, and environmental quality. In this sense, the major activity is devoted to the evaluation of sustainable soil management systems together with the development of associated soil-quality assessments (Doran \& Jones, 1996).

\subsubsection{Quality Types}

Soil has both inherent and dynamic qualities (USDA, 2006). Inherent soil quality is a soil's natural ability to function. For example, sandy soil drains faster than a clayey one. Deep soil has more room for roots than soils with bedrock near the surface. These characteristics are permanent and do not change easily. The inherent quality of soils is often used to compare the abilities of one soil against another, and to evaluate the value or suitability of soils for specific uses. Traditional studies in land evaluation have been basically concerned with the practical interpretation of inherent soil properties (soil suitability) such as inventoried in soil surveys.

Dynamic soil quality is how soil changes depending on how it is managed. Management choices affect the amount of soil organic matter, soil structure, and water- and nutrient-holding capacity. One goal of soil-quality research is to learn how to manage soil in a way that improves its functions. This dynamic aspect of soil quality is the focal point of assessing and maintaining healthy soil resources.

According to the soil factors considered, the soil quality can be physical, chemical, or biological. Most of the physicochemical factors are related to inherent soil quality, and biological and some physical factors with the dynamic soil quality. Although soil quality often focuses on biological aspects, this must not diminish the importance of physical and chemical factors (Ball \& De la Rosa, 2006). 


\subsubsection{Soil Health}

Soil health is the other principle for sustainable soil management used by some soil scientists. Doran et al. (1997) define soil health as the continued capacity of soil to function as a vital living system, within ecosystem and land-use boundaries; to sustain biological productivity; promote the quality of air and water environments; and maintain plant, animal, and human health. In this sense, the soil is considered as a living system, address all essential functions of soil in the landscape, compare the condition of a given soil against its own unique potential within climatic, landscape, and vegetation patterns, and somehow enable meaningful assessments to trends. Although some authors consider the terms soil quality and soil health as synonymous (e.g., Wolfe, 2006), the integrated concept of soil quality can be defined, including the inherent soil quality, traditionally named soil suitability, and the dynamic soil quality or soil health (Fig. 9.1).

\subsubsection{Soil Functions}

The soil system can perform many functions, and often simultaneously. According to Nortcliff (2002), the soil must provide the following basic functions: (i) a physical, chemical, and biophysical setting for living organisms; (ii) the regulation and partition of water flow, storage, and recycling of nutrients and other elements; (iii) support for biological activity and diversity for plant growth and animal productivity; (iv) the capacity to filter, buffer, degrade, immobilize, and detoxify organic and inorganic substances; and (v) provide mechanical support for living organisms and their structures.

Specific soil functions can be defined with respect to issues like particular crop growth, and soil erosion or soil contamination hazard (Table 9.1).

Several soil physical functions, such as water retention and infiltration or soil aeration, are directly connected to the biological status of soil system, as also are the kinds of organisms and nutrient supply. Soil quality is therefore a multifunctional concept. As reported by Imeson et al. (2006), it is well known that overuse or exploitation of some functions (e.g., production function for crops) can lead to the damage of other ones. The spatial and temporal variation in the provision of functions should be incorporated in evaluations or assessments.

\section{Soil quality}

\begin{tabular}{|c|c|}
\hline $\begin{array}{c}\text { Inherent soil quality } \\
\text { (Soil suitability) }\end{array}$ & $+\begin{array}{c}\text { Dynamic soil quality } \\
\text { (Soil health) }\end{array}$ \\
\hline
\end{tabular}

Fig. 9.1 Graphical representation of the soil-quality concept integrating inherent soil quality (or soil suitability) and dynamic soil quality (or soil health) 
Table 9.1 Specific soil functions considered for several soilquality issues

\begin{tabular}{ll}
\hline Soil-quality issue & Soil function \\
\hline Crop growth & Plant root penetration \\
& Plant water-use efficiency \\
& Water- and air-filled pore space \\
& Water infiltration \\
& Nutrient availability \\
Natural fertility & Cation-exchange capacity \\
& Acidity \\
& Salinity/alkalinity \\
& Toxicity \\
& Runoff potential \\
& Erodibility \\
Erosion risk & Cover protection \\
& Subsoil compaction \\
& Workability \\
& Water retention \\
& Water infiltration \\
& Cohesion \\
& Workability/trafficability \\
& Leaching potential \\
& Toxic absorption \\
& Toxic mobility \\
& Chemicals degradation \\
&
\end{tabular}

\subsubsection{Soil Threats}

Consideration of soil threats is crucial for assessing the quality of the soil system. These are the major threats faced by soils: (i) soil erosion, (ii) soil contamination, (iii) decline in organic matter and biodiversity, (iv) soil compaction, (v) salinization, (vi) floods and landslides, and (vii) soil sealing. In many places, soil erosion is the most severe consequence of soil degradation with respect to restoration of soil quality, and controlling erosion is a prerequisite for a healthy soil. However, most of the soil degradation processes are interlinked, and are often linked by similar causative factors. The risk of these soil threats can be monitored by use of indicators such as trends in yields on soils under irrigation to monitor risk of salinity. Actions to protect soil quality necessitate tackling collectively the different threats.

Imeson et al. (2006) provide interesting information of the SCAPE (Soil Conservation and Protection for Europe) project, at different levels of scale, about soil degradation processes and how they are related to soil use and management. Ten case studies are reported by these authors which deal with the main threats to soils in different biogeographic regions in Europe. The general consensus of these case studies is that soil conservation and protection requires a holistic interdisciplinary approach and that integrated actions are required considering all of soil functions. The main task of the SCAPE project was to provide scientific support to the development of the European Soil Strategy to manage soils in a sustainable way and protect them from the many threats they are facing (EC, 2002). 


\subsection{Assessment Procedures}

Any evaluations of soil quality must consider the multiple soil uses (e.g., agricultural production, forest, rangeland, nature conservation, recreation, or urban development). However, the most widely accepted concept of soil quality and the most significant in a global context concerns agro-ecosystems. In soil-quality evaluation or assessment, the two main questions that must be answered are: (i) how does the soil function; and (ii) what procedures are appropriate for making the evaluation. After answering those questions, a range of parameter values or indexes that indicate a soil is functioning at full potential can be calculated using landscape characteristics, knowledge of pedogenesis, and a more complete understanding of the dynamic processes occurring within a soil. Soil-quality assessment focuses on dynamic aspects to evaluate the sustainability of soil management practices, but it must be based on the inherent soil factors.

\subsubsection{Soil-Quality Indicators}

A soil-quality indicator is a simple attribute of the soil which may be measured to assess quality with respect to a given function. It is important to be able to select attributes that are appropriate for the task, given the complex nature of the soil and the exceptionally large number of soil parameters that may be determined, as exemplified in Table 9.2.

Table 9.2 Original geo-referenced soil-profile attributes (morphological, physical, and chemical properties) stored in the SDBmPlus soil database. (Adapted from De la Rosa et al., 2004)

\begin{tabular}{|c|c|c|}
\hline \multirow[b]{2}{*}{ Data block } & \multicolumn{2}{|l|}{ Stored soil profile variables } \\
\hline & Land characteristic type & Number $^{\mathrm{a}}$ \\
\hline Block \#1 & $\begin{array}{l}\text { Site information: Characteristics of the soil profile site, as well as its } \\
\text { identification and classification }\end{array}$ & 62 \\
\hline Block \#2 & $\begin{array}{l}\text { Soil horizon description: Information on the soil morphological and } \\
\text { other characteristics of each horizon }\end{array}$ & 54 \\
\hline Block \#3 & $\begin{array}{l}\text { Standard chemical analyses: Information on the standard analytical } \\
\text { results for sampled horizons }\end{array}$ & 33 \\
\hline Block \#4 & $\begin{array}{l}\text { Soluble salts and heavy metals: Information on the main soluble salts } \\
\text { and on the trace elements related to soil contamination }\end{array}$ & 27 \\
\hline Block \#5 & Physical data: Information on soil physical determinations & 9 \\
\hline Block \#6 & $\begin{array}{l}\text { Water retention and hydraulic conductivity: Up to } 25 \text { determinations } \\
\text { per soil sample quantifying the detailed hydraulic properties }\end{array}$ & 50 \\
\hline Block \#7 & $\begin{array}{l}\text { Additional analytical variables: Up to } 10 \text { specified chemical, physical, } \\
\text { or biological characteristics }\end{array}$ & 10 \\
\hline Block \#8 & $\begin{array}{l}\text { Photographs: Digitized information on site, soil profile, } \\
\text { and other plates }\end{array}$ & 4 \\
\hline Block \#9 & $\begin{array}{l}\text { Metadata: Information on the procedures and methods followed in } \\
\text { preparing soil analysis data }\end{array}$ & 78 \\
\hline Total & & 327 \\
\hline
\end{tabular}

${ }^{a}$ Considering an average of five different horizons per soil profile, these 327 variables can generate more than 1,500 data per soil profile. 
The selection of soil indicators will vary, depending upon the nature of the soil function under consideration. These soil attributes can be classified in three broad groupings: physical, chemical, or biological indicators (Table 9.3). Many of the physical and chemical soil attributes are permanent in time (inherent parameters). In contrast, biological and some physical attributes are dynamic and exceptionally sensitive to changes in soil conditions and in management practices (dynamic parameters). They appear to be very responsive to different agricultural soil conservation and management practices such as nontillage, organic amendments, and crop rotation.

The selection of soil indicator attributes should be based on: (i) land use; (ii) soil function; (iii) reliability of measurement; (iv) spatial and temporal variability; (v) sensitivity to changes in soil management; (vi) comparability in monitoring systems; and (vii) skills required for the use and interpretation (Nortcliff, 2002). As shown in Table 9.3, USDA (2006) select seven physical, three chemical, and two

Table 9.3 Soil attributes which may be used as indicators of soil quality

\begin{tabular}{|c|c|}
\hline Grouping type & Soil indicators \\
\hline Physical attributes & $\begin{array}{l}\text { Soil texture }^{\mathrm{a}} \\
\text { Stoniness } \\
\text { Soil structure }^{\mathrm{a}} \\
\text { Bulk density }^{\mathrm{a}} \\
\text { Porosity } \\
\text { Aggregate strength and stability }^{\mathrm{a}} \\
\text { Soil crusting } \\
\text { Soil compaction } \\
\text { Drainage } \\
\text { Water retention }^{\mathrm{a}} \\
\text { Infiltration }^{\mathrm{a}} \\
\text { Hydraulic conductivity } \\
\text { Topsoil depth }\end{array}$ \\
\hline Chemical attributes & $\begin{array}{l}\text { Color } \\
\text { Reaction }(\mathrm{pH})^{\mathrm{a}} \\
\text { Carbonate content }_{\text {Salinity }} \\
\text { Sodium saturation } \\
\text { Cation exchange capacity } \\
\text { Plant nutrients } \\
\text { Toxic elements }\end{array}$ \\
\hline Biological attributes & $\begin{array}{l}\text { Organic matter content } \\
\text { Populations of organisms } \\
\text { Fractions of organic matter } \\
\text { Microbial biomass } \\
\text { Respiration rate } \\
\text { Mycorrhizal associations } \\
\text { Nematode communities } \\
\text { Enzyme activities } \\
\text { Fatty acid profiles } \\
\text { Bioavailability of contaminants }\end{array}$ \\
\hline
\end{tabular}

${ }^{a}$ Key indicators selected by the USDA (2006) 
biological indicators, which represent a minimal dataset to characterize soil quality. Gomez et al. (1999) define six indicators and threshold values for measuring sustainability of agricultural production systems at farm level. Other examples of soil-quality studies are reported by Doran and Jones (1996) who list soil characteristics as indicators of soil quality.

Critical limits of the soil-quality indicators are the threshold values which must be maintained for normal functioning of the soil system. Within this critical range, the soil performs its specific functions in natural ecosystems. As reported by Arshad and Martin (2002), identification of critical limits for soil-quality indicators poses several difficult problems. For example, a critical limit of a soil indicator can be ameliorated or exacerbated by limits of other soil properties and the interactions among soil-quality indicators.

For many of the soil chemical indicators, there are well-established procedures available for interpreting results. For example in chemical pollution of European soils, the Council Directive 86/278/EEC established a set of critical levels for concentration of heavy metals ( $\mathrm{Cd}, \mathrm{Cu}, \mathrm{Ni}, \mathrm{Pb}, \mathrm{Zn}, \mathrm{Hg}$, and $\mathrm{Cr}$ ). These values should not be exceeded when sewage sludge is applied in agriculture. This directive has been implemented and adapted in the form of several national or regional laws, extending the critical levels to soils in general and not limited to the application of sewage sludge. These precautionary levels are established for the cleaning up of contaminated sites, based on functional criteria and health aspects.

In the case of biological indicators, the interpretation of measurements in relation to crop yield or environmental effects is in its infancy, and there is not yet any agreed scientific basis on which to make such determinations (Wolfe, 2006). For example, increasing soil organic matter provides many benefits; however, it can also have negative environmental and crop production impacts. These negative impacts, such as requirements of many pesticides, greater $\mathrm{P}$ solubility, or higher soil temperature, are rarely considered or significantly weighted in soil-quality assessment (Sojka and Upchurch, 1999).

Comparing soils that have been under a certain use and management system for a number of years with natural soils that have not been disturbed, appears to be an appropriate procedure to assess soil quality by single indicators. The influence of climate, especially distribution of precipitation and temperature, geomorphology, and weathering rate could be eliminated by comparing soils exclusively within an agro-ecosystem or soil type. In this sense, it would be desirable to develop databases of the key soil indicators in natural benchmark soils with latesuccessional vegetation from specific ecosystems. These natural benchmark soils supporting mature vegetation would be used as the high-quality reference soils, because of the ideal balance existing between their physical, chemical, and biological properties. It would be very interesting to develop global catalogs of natural benchmark soils based on the already existing data on agricultural soils, for example, for the Mediterranean Andalusia region (Spain; De la Rosa, 1984). Obviously, these catalogs of natural soils may not be possible due to the high level of disturbance of many soils in many parts of the world. 
Future technological advancements, e.g. satellite remote sensing will obviously have a positive impact on the inventory and monitoring of soil-quality indicators. The latest satellites are already covering the earth with imagery of varied spectral, temporal, and spatial resolutions. The resolutions are from $0.5 \mathrm{~m}$ to $24 \mathrm{~km}$ with days or weeks between coverage of the same area, providing a multitude of new possibilities especially through the geographical information systems (GIS) and decision support systems (DSS) implementation. The use of global positioning system (GPS) allows accurate location of observations made in the field on the inherent and dynamic indicators of the soil quality. Some scientists are using a modern technique of infrared spectroscopy (IR), in conjunction with GPS and satellite remote sensing, for rapid, nondestructive soil characterization and monitoring. From these reflectance fingerprints of soil samples can be predicted and quantified for multiple soil-quality indicators (CGIAR, 2006).

Over the last few years, the ability to extract DNA or ribosomal RNA from cells contained within soil samples, and its direct analysis in hybridization experiments has allowed to detect the presence of a vast diversity of microbes previously unimagined (Thies, 2006). Also, significant progress has been made in the development of specific biomarkers and macromolecular probes, enabling rapid and reliable measurements of soil microbial communities. Also, modern molecular biological techniques, such as fluorescence in situ hybridization (FISH) and denaturing gradient gel electrophoresis (DGGE), have facilitated the analysis of microbial biodiversity and activity; whereas the application of modern analytical techniques, such as nuclear magnetic resonance (NMR) and pyrolysisgas chromatography-mass spectrometry (Py-GC-MS), have provided data on soil chemistry (Arias et al., 2005).

\subsubsection{Soil-Quality Modeling}

Within land evaluation, modeling is the fundamental component for the assessment of inherent soil quality. The models provide a tool for predicting the change in outcome caused by the changes in input parameters. By using land-evaluation models, it is possible to predict the rates and direction of many soil-quality changes. Landevaluation modeling focuses on different purposes which can be grouped in two main classes: land suitability or productivity, and land vulnerability or degradation approaches. For example, Table 9.4 shows the MicroLEIS land-evaluation models according to the evaluated issues (De la Rosa et al., 2004).

The two principal land-evaluation modeling approaches are: (i) empirical-based modeling, and (ii) process-based modeling. The basic idea of empirical modeling for land evaluation is that observed relations are quantified and these once analyzed (i.e., in a limited number of locations) are applicable for predicting future situations. However, this will not work unless there are sufficient data on which to base the inferences, so the methodology is not appropriate for new land uses or areas from which sufficient samples have not been taken. For land evaluations of established 
Table 9.4 MicroLEIS land-evaluation models according to the soil function evaluated and the concrete strategy supported for environmentally sustainable agriculture

Constituent Land-evaluation issue

model (Modeling approach)

Supported strategy

\section{Land-use planning-related}

Terraza

Bioclimatic deficiency

(Parametric)

Cervatana General land capability

(Qualitative)

Sierra

Forestry land suitability

(Qualitative)

Almagra Agricultural soil suitability

(Qualitative)

Quantification of crop water supply and frost risk limitation

Segregation of best agricultural and marginal agricultural lands

Restoration of semi-natural habitats in marginal agricultural lands: selection of forest species

Diversification of crop rotation in best agricultural lands: for traditional crops (12)

Albero Agricultural soil productivity (Statistical)

Quantification of crop yield: for wheat, maize, and cotton

Raizal Soil erosion risk (Expert system)

Marisma Natural soil fertility

(Qualitative)

Identification of vulnerability areas with soil erosion problems

Identification of areas with soil fertility problems and accommodation of fertilizer needs

\section{Soil management related}

ImpelERO Erosion/impact/mitigation

(Neural network)

Aljarafe

Soil plasticity and soil workability (Statistical)

Alcor

Subsoil compaction and soil trafficability (Statistical)

Formulation of management practices: row spacing, residues treatment, operation sequence, number of implements, and implement type

Identification of soil workability timing

Site-adjusted soil tillage machinery: implement

type, wheel load, and tire inflation

Arenal General soil contamination (Expert system)

Pantanal Specific soil contamination (Expert system)

Rationalization of total soil input application

Rationalization of specific soil input application:

$\mathrm{N}$ and $\mathrm{P}$ fertilizers, urban wastes, and pesticides

land uses with sufficient historical or experimental data, such analyses can be very useful and are often the preferred method (Van Lanen, 1991). This empirical-based modeling has moved on from simple qualitative approaches to other procedures that are more sophisticated and based on artificial intelligence techniques.

The linking of the land characteristics with land-use requirements or limitations may be as simple as making statements about land suitability for particular uses, or lands may be grouped subjectively into a small number of classes or grades of suitability. In many qualitative approaches, quantification is achieved by the application of the rule (that is, the minimum law) that the most-limiting land quality determines the degree of land suitability or vulnerability. This assumes knowledge of optimum land conditions and of the consequences of deviations from this optimum (Verheye, 1988). Relatively simple systems of land evaluation depend largely on experience and intuitive judgment; they are really empirical models, and no quantitative expressions of 
either inputs or outputs are normally given. For example, the Land Capability Classification System (USDA, 1961) and its many adaptations have been widely used around the world.

Parametric methods are considered a transitional phase between qualitative methods, based entirely on expert judgment, and mathematical models. They account for interactions between the most significant factors by the multiplication or addition of single-factor indexes. Multiplicative systems assign separate ratings to each of several land characteristics, and then take the product of all factor ratings as the final rating index. These systems have the advantage that any important factor controls the rating. The most widely known method to include specific, multiplicative criteria for rating land productivity inductively was developed by Storie (1933). In the additive systems, various land characteristics are assigned numerical values according to their inferred impact on land use. These numbers are either summed, or subtracted, from a maximum rating of 100, to derive a final rating index. Additive systems have the advantage of being able to incorporate information from more land characteristics than multiplicative systems. The FAO agro-climatic zoning project represents a milestone in the development of land evaluation, introducing a new approach to land-use systems analysis (FAO, 1978).

Expert systems as computer programs that simulate the problem-solving skills of human experts in a given field have been also used. They provide solutions to a problem, expressing inferential knowledge through the use of decision trees. In land evaluation, decision trees give a clear expression of the comparison between land-use requirements and land characteristics. The expert decision trees are based on scientific background and discussions with human experts, and thereby reflect available expert knowledge. Where suitable data on practical experience are available, statistical decision-tree analysis can be used to generate land-evaluation models with good prediction rates (De la Rosa \& Van Diepen, 2003).

Neural networks, as an artificial intelligence technology, have grown rapidly over the past few years and have an ability to deal with nonlinear multivariate systems. An artificial neural network is a computational mechanism that is able to acquire, represent, and compute a weighting or mapping from one multivariate space of information to another, given a set of data representing that mapping. It can identify patterns in input training data which may be missed by conventional statistical analysis. In contrast to regression models, neural networks do not require knowledge of the functional relationships between the input and the output variables. Also these techniques are nonlinear and thus may handle complex data patterns that make simulation modeling unattainable (De la Rosa et al., 1999).

The process-based models for land evaluation have been basically developed to simulate the growth of crops, along with associated phenomena that influence crop growth such as water and solute movement in soil. These simulation models are deterministic and based on an understanding of the actual mechanisms, but used to include a large empirical component in their descriptions of subsystems. The so-called Wageningen models (e.g., WOFOST and CGMS) are based on soil processes and plant physiology to predict yields under several production levels (De la Rosa \& Van Diepen, 2003). 
The Clouds and the Earth's Radiant Energy System (CERES) and Gamma Ray Observatory (GRO) models are probably the most widely known and used dynamic simulation models applied to agricultural production, and which are included in what is now termed Decision Support System for Agro-technology Transfer (DSSAT). The last version of these models can be parameterized to simulate several crops. DSSAT is distributed by the International Consortium for Agricultural Systems Applications (ICASA, 2006). Other dynamic simulation models apply to soil degradation aspects, such as soil erosion (e.g., EPIC, WEPP, EUROSEM), and soil contamination (e.g., LEACHM, MACRO, PEARL). Rossiter (2003) has carried out an interesting review on the application of these biophysical models in land evaluation.

The S-theory of Dexter (2004) proposes the use of an only index of soil physical quality, $\mathrm{S}$. The soil physical quality index, $\mathrm{S}$, is defined as the slope of the soil water retention curve at its inflection point. Examples of poor physical quality $(S<0.035)$ are considered by Dexter when soils exhibit one or more of the following symptoms: poor water infiltration, runoff of water from the surface, hard-setting, poor aeration, poor rootability, and poor workability. Good soil physical quality $(\mathrm{S}>$ 0.035) occurs when soils exhibit the opposite or the absence of the conditions listed above. S-theory appears to be also useful for predicting soil physical quality indicators, for example, hydraulic conductivity, friability, compaction, penetrometer resistance, and root growth.

A major impediment to applying process-based models in soil-quality evaluation is the requirement for high-quality and high-frequency data of soil indicators. However, missing soil indicators can be estimated with pedotransfer functions from routine soil survey data, although these approximations will lead to less successful applications (Pachepsky \& Rawls, 2004). Also, the combination of dynamic simulation models and empirically based land-evaluation techniques are currently producing good scientific and practical results, improving the accuracy and applicability of the models.

\subsubsection{Integrated Approach}

For integrated soil-quality assessment, the development of relationships between all the soil-quality indicators and the numerous soil functions may be a monumental task (Zalidis et al., 2002). Therefore, a stepwise agroecological approach for soil-quality evaluation and monitoring was proposed by De la Rosa (2005). Two steps relating to: (i) inherent soil quality, and (ii) dynamic soil quality are involved (Fig. 9.2).

Step \#1. Land evaluation is an appropriate procedure for analyzing inherent soil quality from the point of view of long-term agroecological changes. Within this complex context, land-evaluation models may serve as a first step to develop a soilquality assessment procedure (Arshad \& Martin, 2002). The first step will result in defining agroecological zones, land suitability, and vulnerability classes, for example, by application of MicroLEIS models (De la Rosa et al., 2004). 


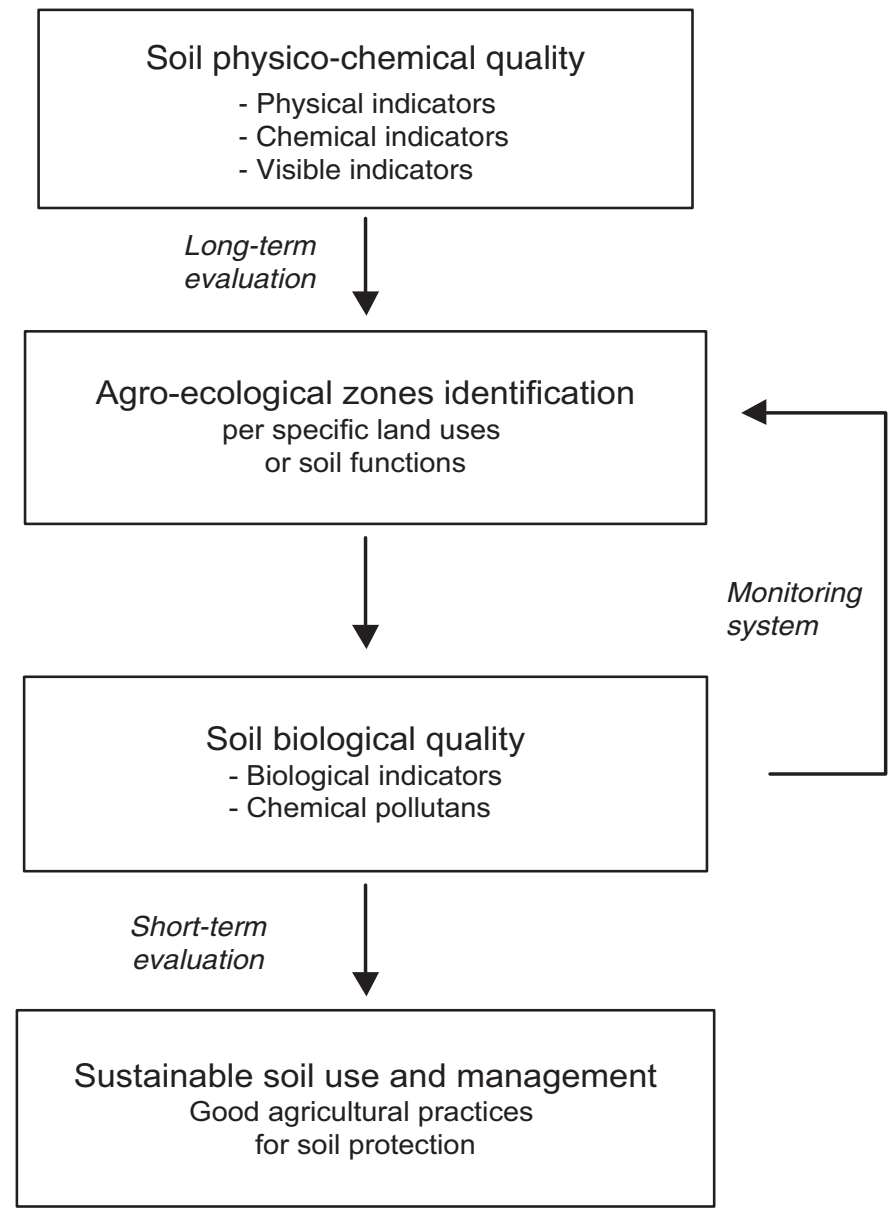

Fig. 9.2 Graphical representation of a stepwise agroecological approach for soil-quality assessment

Step \#2. A short-term evaluation and monitoring procedure would be basically considered for the soil biological quality in each agroecological zone defined in the first step. By measuring appropriate indicators, changes in soil dynamic quality can be assessed. These indicators would be compared with the desired values (critical limits or threshold level), at different time intervals (Arshad \& Martin, 2002). This comparison of single indicators should be of natural soils that have not been disturbed with soils that have been under a certain use and management system for a number of years. Because soil biological parameters are most variable and sensitive to management practices, a monitoring system (observed change over time) would provide information on the effectiveness of the selected farming system, land-use practices, technologies, and policies. For example, dehydrogenase activity in Mediterranean forest soils proved to be very sensitive to both natural and management changes, and showed a quick response to the induced changes (Quilchano \& Marañon, 2002). Also, enzyme activities have been found to be very 
responsive to different agricultural management practices such as nontillage (Bergstrom et al., 1998).

Because of the complex nature of the soil and its high spatial and temporal variability, it is appropriate to develop soil-quality assessment based on biological indicators after the traditional land evaluation using basically physicochemical parameters. This agroecological approach should focus on dynamic soil aspects (biological factors) but with awareness of inherent soil aspects (physical and chemical factors).

In the ensuing section, we present a case study to illustrate the assessment of the inherent and dynamic aspects of soil quality. Land-evaluation models are used to express inherent soil quality, whereas dynamic soil quality is evaluated by assessing the effects of land use and management on soils through monitoring soil properties that more readily respond to use and management.

\subsubsection{A Case Study: Assessing Soil Quality in Argentina}

Background. The Pampean Region covers about 560,000 $\mathrm{km}^{2}$, and includes the provinces of Buenos Aires, Santa Fe, Entre Rios, Cordoba, and La Pampa in Argentina. It has a semihumid to humid subtropical climate with annual precipitation ranging from 800 to $1200 \mathrm{~mm}$. Large interannual variability in rainfall characterizes the region. Mean annual temperature of around $16^{\circ} \mathrm{C}$ occurs in July, the coldest month, whereas January is the warmest month. Altitude varies from 10 to $750 \mathrm{~m}$ with a mean of about $50 \mathrm{~m}$, and slope gradients vary from flat to more than $5 \%$. Formerly, grazing was an important activity, but at present rainfed agriculture is the main economic activity in the region. Conversion of grassland into cropland is the major land-cover process during the last 10 years, accounting for about $28 \%$ of increase of cultivated land area. The major agricultural crops are wheat, maize, soybean, and sunflower (Moscatelli \& Sobral, 2005). The formation of pampean soils is influenced by a flux of eolian materials which originate from unstable desert surfaces. The "pampean loess" are primarily vitric in nature (volcanic glass) and rich in calcium carbonate. Since 2003, the INTA Soil Institute had developed the inventory and monitoring of selected benchmark soil series from Pampa Region, for undisturbed and cultivated sites. This project is based on the previous soil survey studies in the region, where the largest soil map with the largest spatial extent was produced at a scale of 1:500,000 though a major part of the area was also mapped at 1:50,000.

For this case study, the selected benchmark soil is Ramallo series (Figs. 9.3 and 9.4), covering about 232,000 ha in the high plains near to Parana River, in the northwest of Buenos Aires province. The USDA taxonomic classification of a typical pedon of Ramallo series is Fine-loamy, Mixed, Thermic, Vertic Argiudolls, with soil horizons $\mathrm{A}, \mathrm{Bt}, \mathrm{C}$ of a dark grayish brown color, silty clay loam texture, very deep and somewhat poorly drained (Location: $33^{\circ} 40^{\prime} 50^{\prime} \mathrm{S}$ and $60^{\circ} 03^{\prime} 10^{\prime} \mathrm{W}$ ).

Since 1997, the dominant farming system on Ramallo soils is the direct seeding on permanent soil cover (DSPSC), in wheat-soybean rotation (Fig. 9.5). Table 9.5 shows the typical operations sequence corresponding to this farming system for each crop. The DSPSC system is different from conventional agriculture 


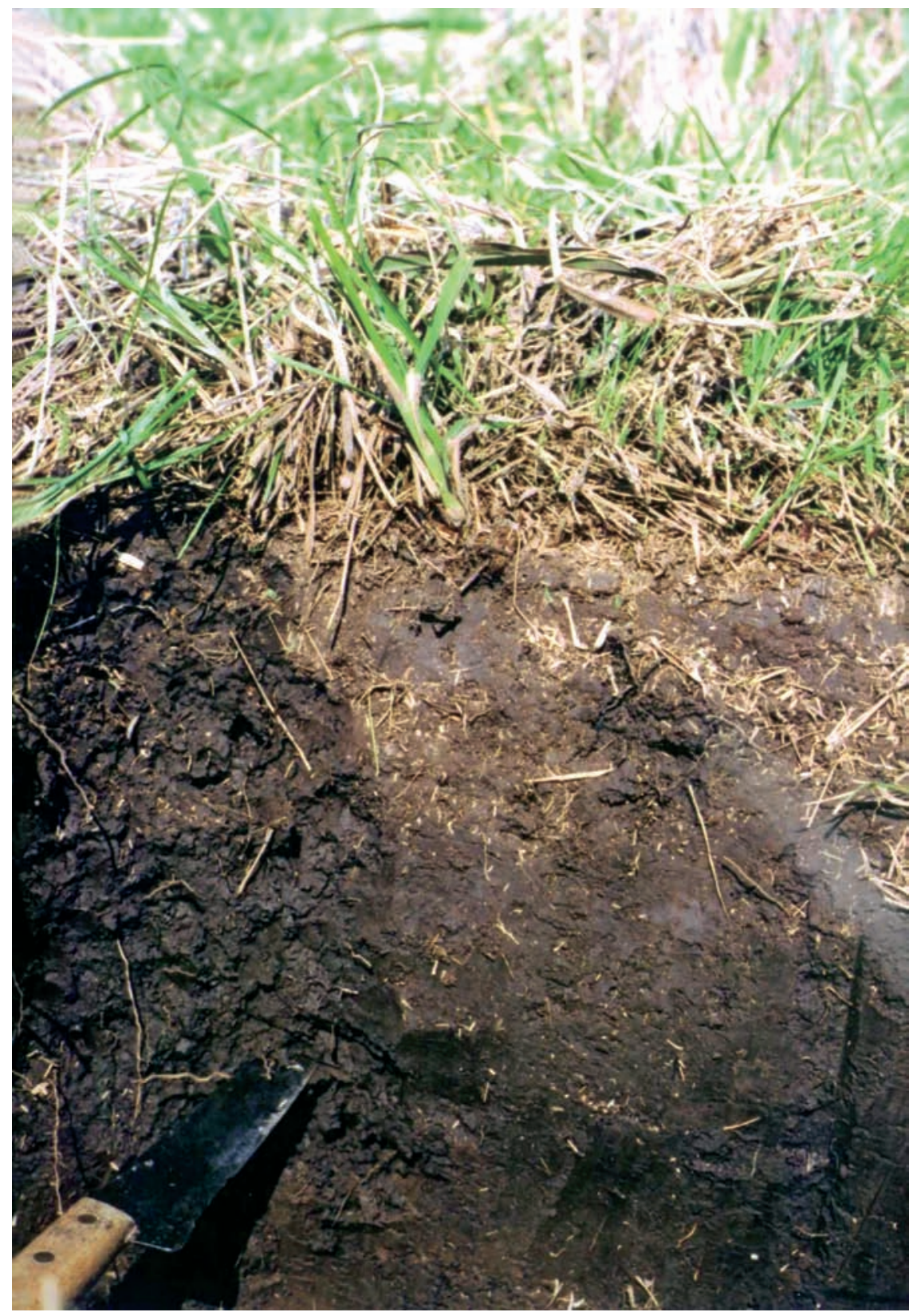

Fig. 9.3 Topsoil of Ramallo series soil, under natural conditions. The A1 horizon has a depth of $31 \mathrm{~cm}$, and an organic matter content of $4.27 \%$ 


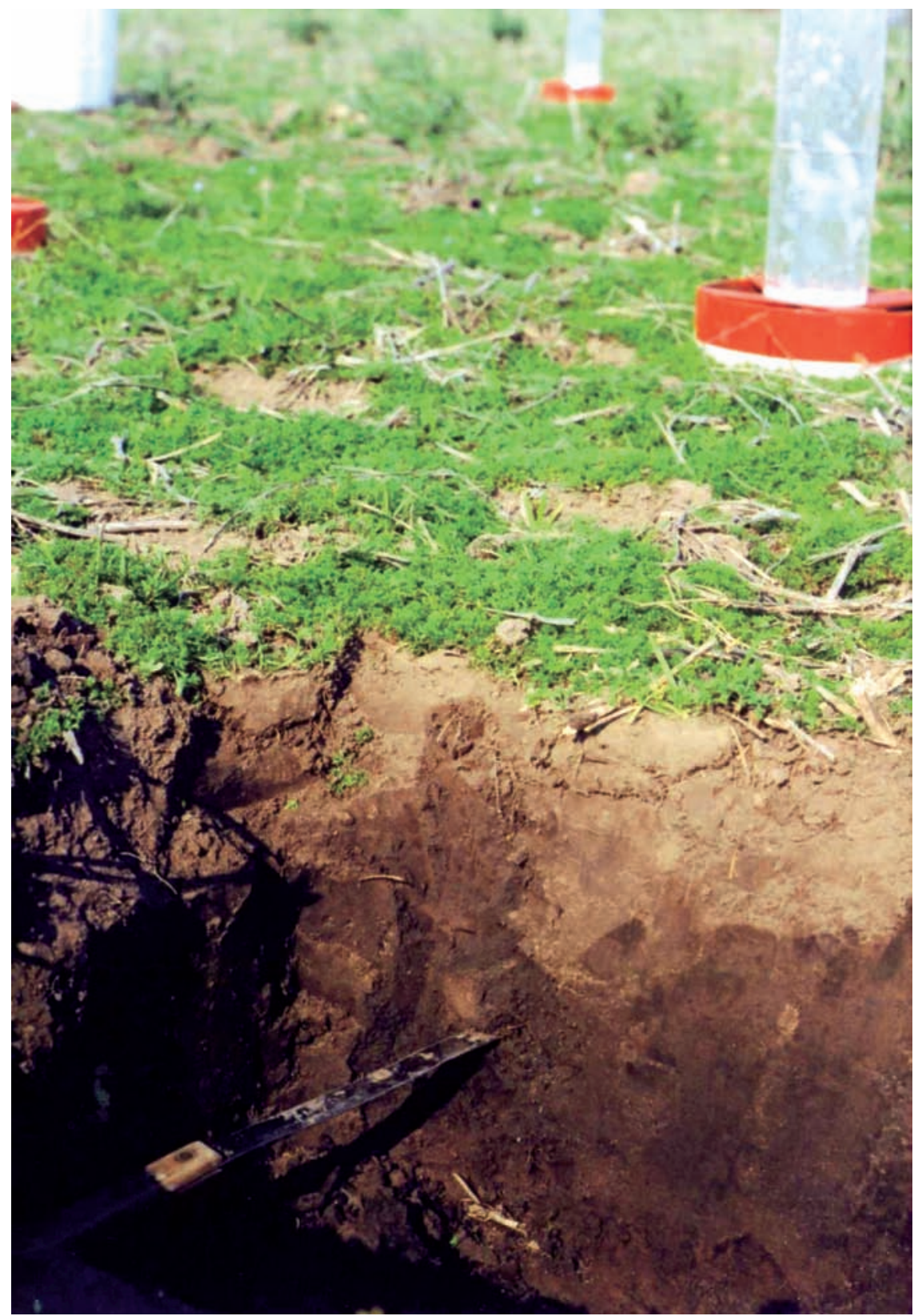

Fig. 9.4 Topsoil of Ramallo series soil, under cultivated conditions. The Ap horizon presents a depth of $18 \mathrm{~cm}$, and an organic matter content of $3.10 \%$ 


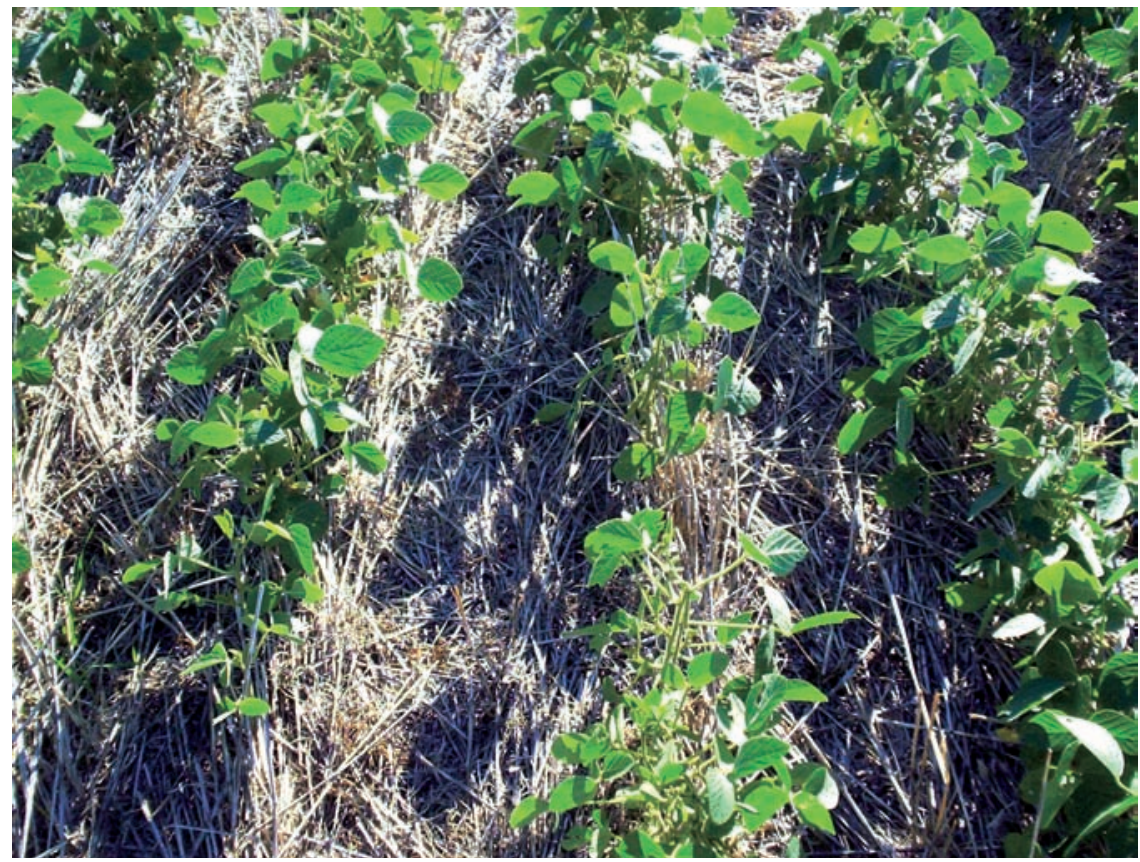

Fig. 9.5 Plot cultivated with direct seeding on permanent soil cover (DSPSC method), soybean crop over wheat stubble on Ramallo soil. The soil cover is not incorporated into the soil by tillage

Table 9.5 Operation sequence of direct seeding on permanent soil cover (DSPSC farming system) on the Ramallo soil in the Pampa region, Argentina

\begin{tabular}{|c|c|c|c|c|}
\hline Operation & Time (month) & Implement type & Material input & $\begin{array}{l}\text { Work rate } \\
(\mathrm{h} / \mathrm{ha})\end{array}$ \\
\hline \multicolumn{5}{|c|}{ Wheat crop } \\
\hline Weed control & June & Motor sprayer & $\begin{array}{l}\text { Glyphosate }(21 / h a)+2-4 D \\
\quad(0.51 / h a)\end{array}$ & 0.40 \\
\hline Crop planting & June & Direct seeder drill & Seed $(130 \mathrm{~kg} / \mathrm{ha})$ & 1.00 \\
\hline $\begin{array}{l}\text { Fertilizer } \\
\quad \text { application }\end{array}$ & June & Direct seeder drill & $\begin{array}{l}\text { Phosfate ammonia (70 kg/ha) } \\
+ \text { Urea }(80 \mathrm{~kg} / \mathrm{ha})\end{array}$ & \\
\hline Weed control & August & Motor sprayer & Metsulphoron $(5 \mathrm{~g} / \mathrm{ha})$ & 0.40 \\
\hline Harvest & December & Combine & & 0.75 \\
\hline \multicolumn{5}{|c|}{ Soybean crop } \\
\hline Weed control & September & Motor sprayer & $\begin{array}{l}\text { Glyphosate }(21 / \text { ha })+2-4 D \\
(0.51 / h a)\end{array}$ & 0.40 \\
\hline Weed control & October & Motor sprayer & $\begin{array}{l}\text { Glyphosate }(21 / \mathrm{ha})+2-4 \mathrm{D} \\
\quad(0.51 / \mathrm{ha})\end{array}$ & 0.40 \\
\hline Crop planting & October & Direct seeder drill & Seed $(80 \mathrm{~kg} / \mathrm{ha})$ & 1.00 \\
\hline Fertilise & October & Direct seeder drill & $\begin{array}{l}\text { Phosphate mono ammonia } \\
\quad(60 \mathrm{~kg} / \mathrm{ha})\end{array}$ & \\
\hline Weed control & November & Motor sprayer & Glyphosate (21/ha) & 0.40 \\
\hline Pest control & December & Motor sprayer & Monocrotophos (0.61/ha) & 0.40 \\
\hline Pest control & January & Motor spray & Endosulfan $(0.61 / \mathrm{ha})$ & 0.40 \\
\hline Harvest & April & Combine & & 0.75 \\
\hline
\end{tabular}


Table 9.6 Comparison of average values ${ }^{\mathrm{a}}$ of soil-quality indicators corresponding to the Ramallo benchmark soil, for natural and cultivated conditions, in the Pampa Region, Argentina

\begin{tabular}{|c|c|c|c|}
\hline $\begin{array}{l}\text { Soil quality } \\
\text { Indicator }\end{array}$ & $\begin{array}{l}\text { Natural conditions } \\
(\mathrm{n}=6)\end{array}$ & $\begin{array}{l}\text { Cultivated conditions } \\
(\mathrm{n}=20)\end{array}$ & $\begin{array}{l}\text { Change intensity, } \\
\%\end{array}$ \\
\hline \multicolumn{4}{|c|}{ Inherent soil quality } \\
\hline Color (humid) & $10 \mathrm{YR} 3 / 2$ & $10 \mathrm{YR} 4 / 2$ & \\
\hline Textural class & Clay silty loam & Clay silty loam & \\
\hline Clay content & 56.5 & 55.4 & 2 \\
\hline Cation exchange capacity & 26.5 & 22.3 & 16 \\
\hline Reaction, $\mathrm{pH}$ & 7.5 & 6.8 & 10 \\
\hline Bulk density $\left(\mathrm{g} \mathrm{cm}^{-3}\right)$ & 1.07 & 1.13 & 5 \\
\hline \multicolumn{4}{|c|}{ Dynamic soil quality } \\
\hline Organic matter content $(\%)$ & 4.3 & 3.1 & 22 \\
\hline Respiration rate $\left(\mathrm{kg} \mathrm{C} \mathrm{ha}^{-1}\right.$ day $\left.^{-1}\right)$ & 83 & 61 & 27 \\
\hline Topsoil loss $(\%)$ & 0 & 31 & 31 \\
\hline Aggregate stability (\%) & 70 & 59 & 16 \\
\hline Infiltration $\left(\mathrm{mm} \mathrm{h}^{-1}\right)$ & 44 & 20 & 55 \\
\hline Compaction (Mpa) & 3.7 & 4.9 & 32 \\
\hline Structure index $(\%)$ & 80 & 53 & 34 \\
\hline
\end{tabular}

${ }^{\text {a }}$ The average values for natural and cultivated conditions correspond to 6 and 20 different sites, respectively. Sampling period: 2003-2005, at planting time.

in that it retains crop residues on the soil surface as a cover, not incorporating them into the soil by tillage. Crop residues are used to form suitable mulch that protects the soil and suppresses weed growth. However, this ground-cover strategy requires herbicides for weed control, especially for the soybean crop (Table 9.5). Therefore, this no-tillage system is characterized by a very high dependency on chemical external inputs. The conventional farming system previously used on these soils included a very intensive soil tillage with several chisel, disk plough, and tine operations.

Step \#1: Inherent soil quality. The single indicators of inherent soil quality presented in Table 9.6 are relatively permanent, and the difference between natural and cultivated conditions is relatively low (2-16\%). According to different agroecological land-evaluation models, the soil and climate information of Ramallo Series have been interpreted as follows.

- USDA (1961) Land Capability Classification: Class II e-Very good soils with few limitations due to soil erosion that reduce the choice of crops or require some conservation practices. This land-evaluation system considers eight capability classes (I to VIII) with a decreasing production potential in terms of expected yield and the range of crops that can be grown. The subclass e represents erosion hazard. 
- FAO (1978) agro-climatic evaluation: $270<$ GPL < 330 days; where GPL is the length of growing period calculated on the basis of the annual precipitation (800-1,200 mm), the annual potential evapotranspiration $(1,100 \mathrm{~mm})$, and the available stored soil moisture $(100 \mathrm{~mm})$. This represents very high biophysical crop production potential under rainfed conditions.

- The Universal Soil Loss Equation (USLE, 1965) erosion risk evaluation: Estimated current soil loss is $20.5 \mathrm{t} \mathrm{ha}^{-1}$ year $^{-1}$. The USLE prescribes $10 \mathrm{t} \mathrm{ha}^{-1}$ year $^{-1}$ as acceptable level of soil erosion. Therefore, Ramallo soils require some conservation practices.

Step \#2: Dynamic soil quality. The dynamic aspect of soil quality is the focal point for maintaining soil health. Dynamic quality results from the changing nature of soil properties that are influenced by human use and management decisions. Collectively, the effects of management will either result in a net positive or negative impact on the quality of the soil. For Ramallo soils, Table 9.6 shows the values measured for some dynamic indicators at natural or undisturbed and cultivated sites. The record of management practices (DSPSC farming system) followed in the cultivated sites is summarized in Table 9.5. The last column of Table 9.6 suggests that several degradation processes are in progress with different intensity. These are mainly subsoil compaction (decrease in infiltration by $55 \%$, and increase in compaction by $32 \%$ ); and water erosion (decrease in topsoil depth by $31 \%$, and organic matter content by $22 \%$ ). Soil contamination by herbicides, which has not been studied on the cultivated soils may be another important degradation process.

\subsection{Soil-Quality Assessment Implementation}

The agroecological land-evaluation support system MicroLEIS (De la Rosa et al., 2004) can be quoted as an example in the application or generalization phase of soilquality assessment approaches. This phase will make possible the practical use of the information and knowledge gained during the prior phase of developing assessment procedures. The MicroLEIS system was developed to assist specific types of decision-makers faced with specific agroecological problems in the Mediterranean region. It has been designed as a knowledge-based approach which incorporates a set of information tools, as illustrated in Fig. 9.6. Each of these computer-assisted procedures is directly linked to others, and customized applications can be carried out on a wide range of problems related to land productivity and land degradation.

\subsubsection{Data Warehousing}

Data warehousing can be greatly facilitated if the nearly infinite list of basic attributes is systematically arranged and stored in an ordered format for ready 

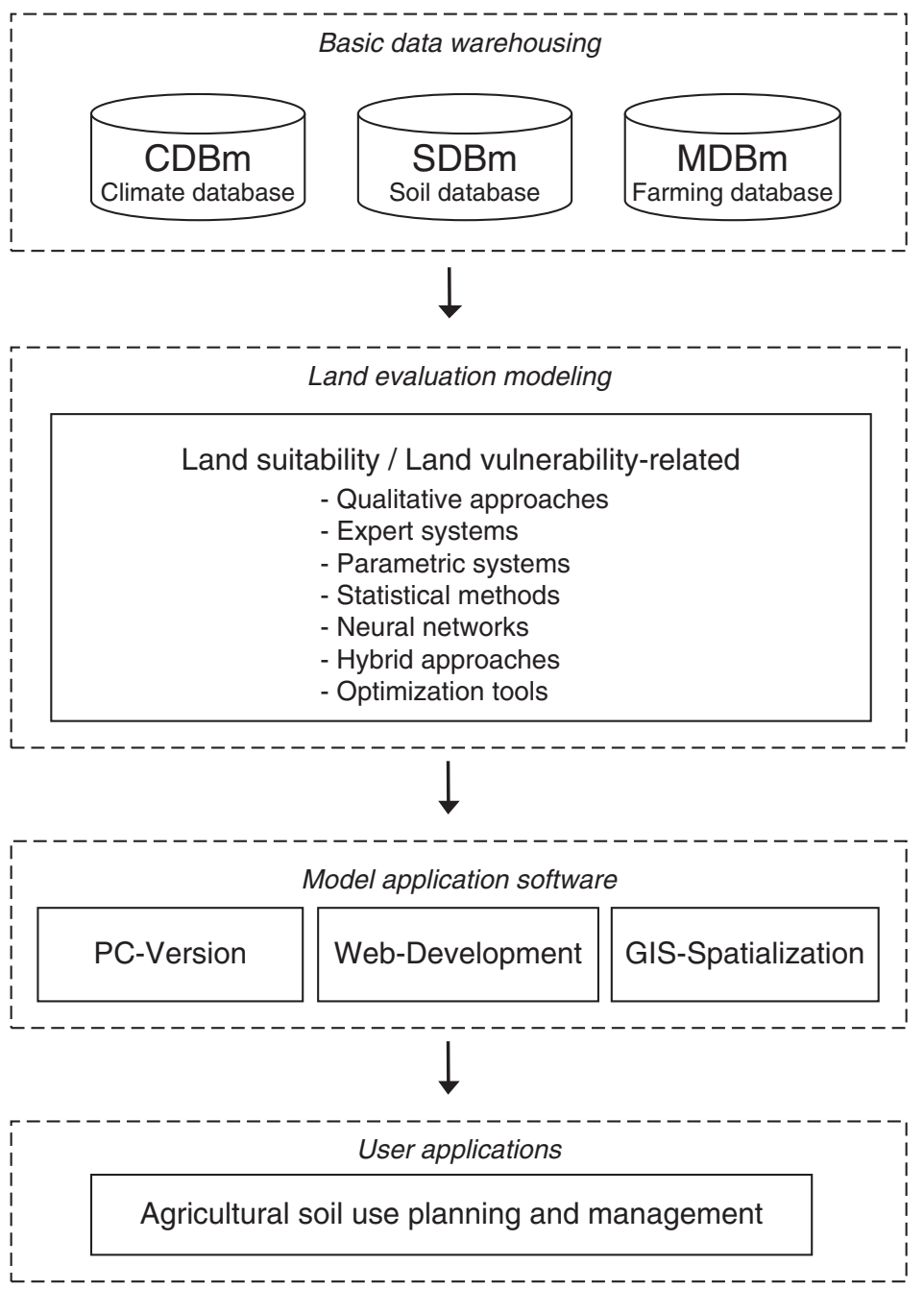

Fig. 9.6 Conceptual design and component integration of the MicroLEIS DSS land-evaluation decision support system. (Adapted from De la Rosa et al., 2004. With permission)

sorting and retrieval. Database management systems are responsible for these tasks and consist of attribute tables manipulated by relational database management systems, and a geometric component handled by GIS.

The land attributes used in MicroLEIS correspond to the following three main factors: soil/site, climate, and crop/management. Soil surveys are the building blocks of the comprehensive data set needed to drive land evaluation. Land evaluation is normally based on morphological, physical, and chemical data derived from the soil survey, such as soil depth, texture, water capacity, drainage class, soil reaction, and organic matter content. Other biophysical factors, mainly referred to 
monthly climate parameters, are also considered land characteristics. Because climatic conditions vary from year to year, reliable long-term data are used to reflect the historical reality and to predict future events with some degree of confidence. Traditionally, agricultural management aspects have been considered a prerequisite only in land evaluation. Today, management factors are being incorporated as input variables in response to a growing need for integrating farming information. In this sense, crop and management data derived from field observation, monitoring, or experimentation, such as growing-season length, rooting depth, tillage operations, and treatment of residues, are also considered land characteristics.

For each of these main factors, a relational database has been constructed: SDBm Plus, CDBm, and MDBm, with connections between the three databases. The multilingual soil database SDBm Plus (De la Rosa et al., 2002) is a geo-referenced soil attribute database for storage of an exceptionally large number of morphological, physical, and chemical soil profile data. This database is the "engine" of the MicroLEIS DSS system. It is a user-friendly software designed to store and retrieve efficiently and systematically the geo-referenced soil attribute data collected in soil surveys and laboratories. As illustrated in Fig. 9.7, the SDBm Plus database has the following main characteristics: (i) running on WINDOWS platforms; (ii) "help menus" facilitating data entry; (iii) automatic translation from English to Spanish, French, and German; (iv) metadata feature to describe the methods used in laboratory analysis; (v) temporal mode to collect over time physical and hydraulic soil properties; (vi) structured query procedure to allow detailed searches; (vii) simple graphical analyses and report generation; and (viii) an input file generator for the automatic transfer of the stored soil attribute data to GIS and computerized landevaluation models. The SDBm Plus database was developed by the MicroLEIS Group with the collaboration of FAO through a joint project (FAO-CSIC, 2003).

The climate database CDBm developed for MicroLEIS DSS is a computerbased tool for the organization, storage, and manipulation of agro-climatic data for land evaluation. These geo-referenced climate observations from a particular meteorological station correspond to the mean values of such records for a determinate period. The basic data of CDBm are the mean values of the daily dataset for a particular month. The stored mean monthly values correspond to a set of temperature and precipitation variables (maximum temperature, minimum temperature, accumulative precipitation, maximum precipitation per day, and days of precipitation).

The farming database MDBm is knowledge-based software to capture, store, process, and transfer agricultural crop and management information obtained through interviews with farmers. Each MDBm dataset consists of geo-referenced agricultural information on a particular land-use system. This structured collection of information is stored as a database file. A menu system guides the user through a sequence of options to capture the management practices followed on a site-specific farm. Input parameters are farm and plot descriptions, crop characteristics, sequence of operations, and behavioral observations. These parameters represent a total of 59 default variables according to good management practices on Mediterranean farms. 


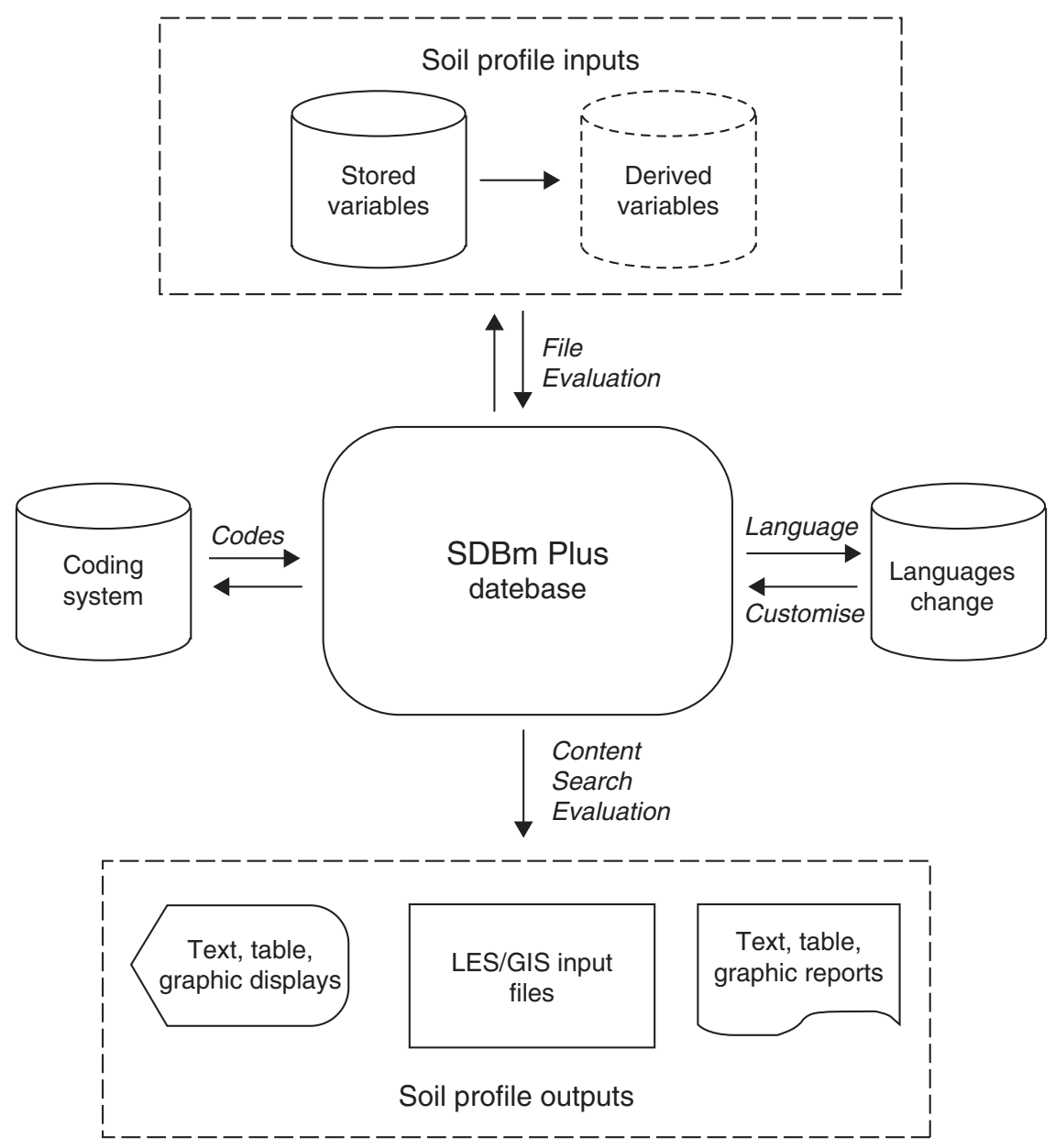

Fig. 9.7 General scheme of the SDBm Plus database. (Adapted from De la Rosa et al., 2002. With permission)

\subsubsection{Modeling Integration}

The possibilities for using land-evaluation models in decision-making by developing the model application software are enormous. This integration phase will make possible the practical use of the information and knowledge gained during the prior phase of building evaluation models (Antoine, 1994). When the assessment models are expressed in notations that can be understood by a calculating device, the algorithms become computer programs. In order to put the models to use in practical applications, that is, to automate the application of land-evaluation models, a library of PC-based software is developed. A graphical interface is 
designed which will allow the models to be easily applied. This user interface is considered a very important component because, to the user, it is the system.

Within the MicroLEIS framework, the PC-based software has been written using various programming languages, particularly Basic and $\mathrm{C}++$. It has the following main characteristics: (i) input data through the keyboard and connection with the attribute databases; (ii) "pop up" screens showing codes, types, and classes of input variables; (iii) models running in individual and batch-processing modes; (iv) output evaluation results in window, printout, and file formats; and (v) links of output files with GIS databases. These computer programs are largely self-explanatory.

The model computer programs can also be implemented on the Internet through a World Wide Web (WWW) server, so that users can apply the models directly via a Web browser. It is not necessary to download and install the PC software. These open-access WWW applications offer several advantages, such as their use by many people, allowing their usability to be checked in order to improve the systems. Upgrades are immediately made available on the WWW server. The Web site is the center of activity in developing operative planning or decision support systems.

\subsubsection{Application Tools}

Spatial decision support systems for policymakers and land users must focus on choosing optimal use and management decisions. In this sense, optimization tools based on land-evaluation models are very important in formulating decision alternatives - for example, agricultural management practices to minimize threats to the sustainability of farming systems. Agricultural management operations depending on spatially varying land characteristics have the added difficulty of trying to satisfy multiple, and often opposing, aims: the best soil conditions for plant growth may not be the best with regard to erosion or pollution.

Within the MicroLEIS, the optimization tools are used in conjunction with running various models. On the basis of the quadratic version of the Albero model, a mathematical procedure was developed to determine a combination of input variables to maximize predicted yields. This procedure involved taking the first mathematical derivative with respect to each independent variable, setting it to zero, and solving the system of simultaneous equations (De la Rosa et al., 1992). On the basis of the expert-system/neural-network structure of the ImpelERO model, a computerized procedure was followed to find an appropriate combination of management practices to minimize soil loss for a particular site (specified climate and soil characteristics). This formulation of specific crop management for soil protection of each particular site is one of the most interesting features of the ImpelERO model (De la Rosa et al., 2000).

Spatial or regional analysis includes the use of spatial techniques to expand landevaluation results from point to geographic areas, using soil survey and other related maps. The use of GIS technology leads to the rapid generation of thematic 
maps and area estimates, and enables many of the analytical and visualization operations to be carried out in a spatial format, by combining different sets of information in various ways to produce overlays and interpreted maps. Furthermore, digital satellite images can be incorporated directly into many GIS packages. This technology is a prerequisite for managing the massive datasets required for spatial land-evaluation application-a simple map subsystem (e.g., ArcView) being all that is required to show basic data and model results on a map, or to extract information from maps to be used in the land-evaluation models.

The option "Spatialization" of MicroLEIS was developed as a further stage of the scaling-up process of evaluation models application. GIS technology was used to extract information from maps to be used in the predictive models, and to show model results on a map. The evaluation results are estimated by grid cells and aggregated to regional level. The soil survey maps, which in geographical format are usually polygonal multifactor maps, are the main source of basic information. Additional basic information can be extracted from other soil-survey-related maps, such as land-use maps. At the regional scale, part of the basic information for applying MicroLEIS land-evaluation methods can be facilitated by single-factor grid maps, such as digital terrain models, along with satellite images (De la Rosa et al., 2004).

\subsection{Sustainable Management Practices}

Rule number one is that universal recommendations on sustainability of soil management practices must not be done. It is clear that each particular site (combination of climate, soil type, and land use) requires a different set of management practices, but several general principles can apply in most situations. These general principles on sustainable agricultural practices focus on the positive effects on soil quality: (i) increased organic matter, (ii) decreased erosion, (iii) better water infiltration, (iv) more water-holding capacity, (v) less subsoil compaction, and (vi) less leaching of agrochemicals to groundwater. All these soil-quality conditions are essential for the proper functioning of soil, and one or two of them alone will not be enough. They can be analyzed in relation to the following groups: (i) arable land identification, (ii) crop diversification, (iii) organic matter restoration, (iv) tillage intensity, and (v) soil input rationalization.

\subsubsection{Arable Land Identification}

Agricultural management systems located on the most suitable arable lands, according to their agroecological potentialities and limitations, is the first step to achieve soil sustainability. On the contrary, any kind of agricultural management system will have a negative environmental impact when applied on land with very low suitability 
for agricultural uses. Marginal agricultural land under any kind of farming system used to be the ideal scenario for soil erosion. Therefore, a positive correlation between current land use and potential land capability would be desirable, beginning with the identification of the best agricultural lands.

It is clear that in many marginal agricultural lands, it can be necessary to change the land-use system fundamentally by conversion from arable to forest or pasture. For example, the case of a Mediterranean region: Andalusia, as shown in Table 9.7 the relationship between present land use (current use) and agricultural land capability (potential use) is clearly unbalanced (De la Rosa \& Moreira, 1987). About 1 million ha of rainfed agricultural lands must be converted to forestry, grazing, or natural lands in order to get a better equilibrium in comparison with the moderately or clearly marginal lands. Similar situations are very frequent in other European regions, and it is the major reason for the reforestation programs launched by the European Commission.

\subsubsection{Crop Diversification}

Crop diversity is beneficial for several reasons. Each crop contributes a unique root structure and type of residue to the soil. A diversity of organisms can help control pest populations, and a diversity of cultural practices can reduce weed and disease pressures. Diversity across the landscape and over time can be increased by using buffer strips, small fields, contour strip cropping, crop rotations, and by varying tillage practices. Changing vegetation across the landscape or over time increases plant diversity, and the types of insects, microorganisms, and wildlife (USDA, 2006). In contrast, simplification of crop rotation as a relevant element of arable intensification has led to soil deterioration and other negative environmental impacts.

Table 9.7 Comparison of present land uses and agroecological land-capability classes in Andalucia region, Spain

\begin{tabular}{lcc}
\hline Category & $\begin{array}{l}\text { Estimated extension } \\
\left(10^{3} \text { ha }\right)\end{array}$ & $\begin{array}{l}\text { Percentage } \\
(\%)\end{array}$ \\
\hline Irrigated agricultural lands & 592 & 7 \\
& $\begin{array}{l}\text { Present land use } \\
\text { Rainfed agricultural lands }\end{array}$ & 3,165 \\
Forestry, grazing and natural lands & 4,007 & 36 \\
Others & 936 & 46 \\
& Land capability class & 11 \\
S1. Excellent agricultural lands & 535 & 6 \\
S2. Good agricultural lands & 1,735 & 20 \\
S3. Marginal agricultural lands & 2,311 & 27 \\
N Nonagricultural lands & 4,073 & 47 \\
\hline
\end{tabular}


Within the agricultural lands, all soils can be used for almost all crops if sufficient inputs are supplied. The application of inputs can be such that it dominates the conditions in which crops are grown, such as it can be the case in greenhouse cultivation. However, each soil unit has its own potentialities and limitations (soil suitability), and each crop its biophysical requirements. In order to minimize the socioeconomic and environmental costs of such inputs, the second major objective in managing soil quality is to predict the inherent suitability of a soil unit to support a specific crop for a long period of time. This kind of study provides a rational basis to diversify agricultural soil system considering all the possible crops (De la Rosa \& Van Diepen, 2003).

\subsubsection{Organic Matter Restoration}

Increasing soil organic matter level is critical because organic matter is related to many aspects of soil physical, chemical, and biological quality. Organic matter improves soil structure, water-holding capacity, nutrient availability, biological activity, and can help protect against erosion and compaction. Also, soil organic matter restoration could remove significant amounts of carbon dioxide from the atmosphere (see Chapter 2).

Better crop yields that produce more crop residues to incorporate into the soil are the best way to increase stable soil organic matter. Burning the straw or stubble after harvest is a practice not recommended. Further additions may come from animal manure, green manure, and sewage sludge and biosolid wastes when properly and safely recycled. To do the last, it is necessary to select the more appropriate kind of soil to receive these wastes. For example, calcareous soils appear to be the most suitable, considering the important role of calcium for increasing the efficiency of accumulation of soil organic matter. Also, soil contamination vulnerability, specially referred to heavy metals, must be considered in selecting appropriate application sites.

In general terms, it has been estimated that an annual return of $5 \mathrm{t} \mathrm{ha}^{-1}$ of crop residues could keep soils in equilibrium with present levels of soil organic matter (Wallace, 1994). In the Mediterranean region, where it is hotter, some more tons per ha will be needed. The efficiency of conversion of such carbon to stable soil organic matter is not constant and is a function of several variables.

\subsubsection{Tillage Intensity}

Soil tillage has positive agricultural effects, preparing suitable seedbeds for crops; controlling weeds; and incorporating manure, fertilizers, pesticides, and other amendments. At the same time, the negative consequences of tillage practices accelerate soil erosion and compaction process, by destroying soil organic matter and soil 
structure. To formulate the tillage type and intensity for each particular soil is critical for tackling soil degradation problem in agricultural lands (De la Rosa et al., 1999).

In general terms, tillage systems can range from full-width intensive tillage to zero tillage (i.e., intensive tillage, reduced tillage, ploughless tillage, minimum tillage, and no-tillage). The most common intensive tillage system of dry farming consists of moldboard ploughing to break the hardened soil surface, and many successive disking and harrowing to reduce soil-clod size. Traditional tillage implements (e.g., plow moldboard or disk cultivator) which cause soil inversion can be especially appropriate for high-slope soils due to increase surface roughness $(>30 \mathrm{~mm})$. Increasing the surface roughness (micro-topography) along the contour direction decreases the transport capacity and runoff detachment by reducing the flow velocity. During a rainfall event, rough surfaces are eroded at lower rates than smooth surfaces under similar conditions. The soil workability status for each soil and tillage operation is very related with the produced surface roughness and other soil physical properties. The soil workability status ("tempero" in Spanish language) is considered as the optimum soil water content where the tillage operation has the desired effect of producing the greatest proportion of small aggregates (Dexter \& Bird, 2001). Beyond this soil water range, soil is too wet or too dry, and therefore the tillage operation alters in an adverse way the soil physical properties and facilitates soil erosion. By taking into account the water workability limits for each soil and tillage operation, it is possible to reduce the effects of soil erosion. Soil workability and its influence on soil tillage is widely analyzed by Dexter (2004) as an important aspect of his interesting S-theory on soil physical quality. Subsoiling, deep ploughing, para-ploughing, and numerous other tillage implements can be used to alleviate the problems created by subsoil compaction.

However, this conventional repeated tillage system accelerates decomposition of organic matter thus affecting soil physical, chemical, and biological attributes of soil quality (Moreno et al., 2006). Topsoil pulverization by repeated tillage and under dry soil conditions has a very negative effect on erosion. Finely pulverized soils are usually smooth, seal rapidly, and have low infiltration rates, as might be the case for some roto-tilling operations or for repeated cultivations of silt loam soils under Mediterranean conditions. The subsoil compaction caused by tillage and traffic with increasing weight of agricultural machinery is a problem especially severe in heavy-textured and poorly drained soils. Increased soil-bulk density reduces air permeability, water infiltration, and sometimes root development. An intensive tillage system is clearly inappropriate for most soils and must be avoided to minimize soil erosion.

With the no-tillage system or DSPSC (also named conservation agriculture) the soil is left undisturbed, including direct sowing and weeds control accomplished with herbicides. Although there are several forms of conservation agriculture, normally it is considered synonymous with no-tillage systems. The DSPSC system is gaining popularity among farmers from South America and USA. In 2002, Derpsch and Benites (2003) calculated that the total world area covered was 72 million ha, with $46 \%$ corresponding to South America and $31 \%$ to USA. There is overwhelming 
evidence from several scientific studies that continuous no-tillage in some agro-ecosystems is the most effective and practical approach for restoring and improving soil quality (Arshad, 1999). With successful conservation agriculture, the loss of soil organic matter can be very much reversed. The erosion risk decreases as the soil surface is continuously covered, mainly during the rainy season. Conservation agriculture, which provides a high level of crop residues, increases the biodiversity level-more wildlife and soil fauna. In Mediterranean agro-ecosystems, the best results of no-tillage system seem to be obtained on the heaviest clay soils (Gomez et al., 1999).

However, the level of success of this agriculture varies with (i) site and climatic conditions, (ii) soil type, (iii) crop species, and (iv) growing period length. So, high slope gradient $(>15 \%)$ appears to be a limiting factor to introducing conservation agriculture (Martinez-Raya, 2003). With special reference to the Mediterranean region, in soils with low water infiltration rate and prone to surface sealing the effects of no-tillage can increase runoff generation and erosion problem (Gomez et al., 1999). A short growing-period length (GPL < 250 days; e.g., in Scandinavian or Mediterranean agro-ecosystems) is considered a barrier to adoption of no-tillage system, due to stunted development of the mulching horizon (Arshad, 1999). The GPL is one of the major parameters in agro-ecological zoning studies (land-use planning). The increased density of the soil just beneath the depth of tillage (subsoil compaction) is one of the most striking effects of management system, specially plough-less tillage. Because in many cases the mulch cover is not sufficient to suppress weed growth, it is needed to use herbicides to control weeds, increasing the soil-contamination risk by leaching of agrochemical to groundwater.

In summary, the general trend in soil tillage system would be to (i) reduce tillage intensity, (ii) follow the contour for tillage direction, (iii) diversify tillage implements, (iv) reduce subsoil compaction, and (v) consider optimum soil workability.

\subsubsection{Soil Input Rationalization}

Over the last four decades, it is evident that chemical applications have revolutionized agriculture. On the positive side, fertilizers and pesticides have increased crop production and the amount of organic matter returned to the soil. However, soil and water contamination is very high in many places with increased agricultural intensification. Independently of the nutrient needs for crop yield, the application of fertilizers usually exceeds the functional capacity of the soil to retain and transform such nutrients. In many cases, the saturation of the soil with nitrogen and phosphate has led to losses of nitrates into shallow groundwater and saturation of the soil with phosphate, which may also move into the groundwater (Zalidis et al., 2002).

The risk of applying manure and urban wastes (basically sewage sludge and compost) on agricultural soil must be considered based on three components relevant to soil protection: organic matter content, nutrient load, and contaminant load. 
The maximum risk from the extensive use of pesticides is due to leaching and drainage of pesticides into the surface- and groundwater. Several soil functions can be degraded, including the food web support, the retention and transformation of toxicants and nutrients, and soil resilience. The frequent use of herbicides is drastically changing the methods of crop production, but their impacts on soil quality/ degradation are still not known exactly. The exclusive chemical weed control must be identified as an important limiting factor in the adoption of the no-tillage system. In this case, the risk of soil contamination by herbicides must be analyzed because, ironically, farming practices to remedy eroded soils can increase soil degradation by contamination.

\subsubsection{Innovative Examples}

In the decades ahead, the development of sustainable agricultural systems will require great improvements, not just through biotechnology and chemical use but also via agro-ecological innovations (Uphoff, 2002). As referred by some authors, in the future "a doubly green revolution" will be necessary that reverses environmental deterioration at the same time that it augments the supply of food. This section makes reference to a variety of innovative agro-ecological methods, basically interventions that target biological processes, already used to have a positive impact on soil quality and crop production: (i) agroforestry interventions, such as the addition of "tithonia" as a green manure; (ii) conservation agriculture with notillage, now evolving into comprehensive soil management strategies; (iii) small farm management, by a combination of terracing, windrows, applications of manure, water harvesting, etc.; (iv) bio-intensive agriculture, including doubledug beds, optimal spacing of plants, use of organic nutrients, and other "permaculture" techniques; (v) soil bio-rehabilitation methods, introducing new vegetation that supports intensified microbial interactions, rhizobia, mycorrhizal, trichoderma, etc., as a kind of microbiological weathering of the soil; (vi) managed fallows to fertility recovery, by planting and managing certain plants, for example, Crotalaria and Chromaleana, in fallow rotation systems; (vii) green manure and cover crops, to restore degraded soils or raise productivity of cropped soils; (viii) modification of soil horizons, breaking up lower soil horizons and aerating them to a depth of several feet; (ix) composting and vermicomposting, combining worm action and composting to change soil organic matter, both in quantity and in quality; (x) slash-and-char cultivation, incorporating incompletely burned charcoal in the soil; (xi) polycropping management, to control plant pests through selected mixes of crops; and (xii) biological remediation of pesticides, heavy metals, and other contaminants, by microorganisms genetically engineered to break down or take up contaminants. Uphoff et al. (2006) presents an interesting "stateof-practice" review on these biological strategies for a new agriculture. The book provides a comprehensive understanding of the science and steps needed to utilize soil systems for sustainable agriculture. 


\subsection{Conclusion}

Maintenance and improvement of soil quality is one of the most important prerequisites to achieve the environmental sustainability. In spite of the huge controversy (Sojka \& Upchurch, 1999), the modern concept of soil quality is a valid and important framework in interpreting scientific soil information and predicting sustainable soil use and management. However, the process of evaluating soil is not new, and agro-ecological land evaluation, developed since the middle of the twentieth century (Davidson, 1992), has much to offer in the complex task of soil-quality assessment.

Soil-quality indicators are valuable tools and are finding increasing application. However, dynamic soil indicators should be measured after estimation of inherent soil indicators. An agroecological approach follows two steps: (i) developing longterm, inherent, specifically physicochemical evaluation, and (ii) short-term, dynamic, specifically biological evaluation (De la Rosa, 2005). The focus on biological approaches must not diminish appreciation of the physical and chemical factors, in order to develop a productive integration of the three sets of factors. The selected case study points out that soil-quality aspects are inherent and dynamic, and that can be measured and explained through land-evaluation modeling and simple indicators comparison, respectively. The analyzed DSPSC system can be considered a mulch-based management system adapted to the particular condition of Ramallo soils in Argentina, although with the major disadvantages of high dependence on chemical inputs (mainly herbicides) and limited crop diversification because of the need of cereals in the crop rotation.

Modern technologies are providing unprecedented power and flexibility plus the possibilities to combine soil-quality information and knowledge in novel and productive ways. The agroecological land-evaluation decision support system such as MicroLEIS reflects the many advances in these technologies and their possibilities for the development and application to soil-quality assessment (De la Rosa et al., 2004).

Sustainable soil management can maintain and even improve soil quality through the use of soil-specific practices, adapted to local soil, terrain, and climatic conditions, by using decision or planning support tools. The agro-ecological paradigm for a new agriculture defended in this chapter needs to be considered under two central perspectives: site specificity and time dimension. However, several general principles can apply in most situations across international boundaries. These basic principles on sustainable agricultural practices focus on the positive effects on the soil quality: (i) increased organic matter, (ii) decreased erosion, (iii) better water infiltration, (iv) more water-holding capacity, (v) less subsoil compaction, and (vi) less leaching of agro-chemicals to groundwater. To achieve these objectives, the following sustainable soil use and management strategies will be developed: (i) arable land identification, (ii) crop diversification, (iii) biomass restoration, (iv) appropriate tillage intensity, and (v) soil input rationalization. 
In the future, a postmodern agriculture has potential for great improvement, not just through biotechnology and the use of chemicals but also via agroecological innovations in order to increase the crop production and environmental protection. This will depend crucially on soil quality and the methods for its assessment; being an area of knowledge generation and practical application where the science is still young. It can be anticipated that farmers from different geographical contexts will begin to want to apply information technology to support many soil-specific operational aspects of farming in the future, for example, real-time decision support systems (Thysen, 2000).

Acknowledgments The authors would like to thank Prof. D. Davidson, University of Stirling (Scotland, UK), for his constructive comments on this chapter and suggestions for modifications. Thanks are also expressed to Ing. Roberto Casas, Director INTA Soil Institute in Argentina, for his collaboration in developing the case study.

\section{References}

Antoine, J. (1994). Linking geographical information systems (GIS) and FAO's agro-ecological zone (AEZ) models for land resource appraisal. FAO World Soil Resources, Report 75. Rome, FAO.

Arias, M. E., Gonzalez-Perez, J. A., Gonzalez-Vila, F. J., \& Ball A. (2005). Soil health-a new challenge for microbiologists and chemists. International Microbiology, 8, 13-21.

Arshad, M. A. (1999). Tillage and soil quality: Tillage practices for sustainable agriculture and environmental quality in different agro-ecosystems. Soil \& Tillage Research, 53, 1-2.

Arshad, M. A., \& Martin, S. (2002). Identifying critical limits for soil quality indicators in agroecosystems. Agriculture, Ecosystems \& Environment, 88, 153-160.

Ball, A., \& De la Rosa, D. (2006). Modeling possibilities for the assessment of soil systems. In: N. Uphoff, A. Ball, E. Fernandes, H. Herren, O. Husson, M. Laing, Ch. Palm, J. Pretty, P. Sanchez, N. Sanginga, \& J. Thies (Eds.), Biological approaches to sustainable soil systems (pp. 683-692). Boca Raton, FL: Taylor \& Francis/CRC Press.

Bergstrom, D. W., Monreal, C. M., \& King, D. J. (1998). Sensitivity of soil enzyme activity to conservation practices. Soil Science Society of America Journal, 62, 1286-1295.

CGIAR. (2006). Consultative Group on International Agricultural Research. Available at http:// www.cgiar.org. (Retrieved on 24 February 2006.)

Davidson, D. (1992). The evaluation of land resources. Harlow, Essex, UK: Longman.

Davidson, D. (2000). Soil quality assessment: Recent advances and controversies. Progress in Environmental Science, 2, 342-350.

De la Rosa, D. (Ed.) (1984). Catalogo de suelos de Andalucia. Sevilla, Spain: Agencia de Medio Ambiente, Junta de Andalucia.

De la Rosa, D. (2005). Soil quality evaluation and monitoring based on land evaluation. Land Degradation \& Development, 16, 551-559.

De la Rosa, D., \& Moreira, J. M. (Eds.) (1987). Evaluacion agro-ecologica de recursos naturales de Andalucia. Sevilla, Spain: Agencia de Medio Ambiente, Junta de Andalucia.

De la Rosa, D., Moreno, J. A., Garcia, L. V., \& Almorza, J. (1992). MicroLEIS: A microcomputerbased Mediterranean land evaluation information system. Soil Use \& Management, 8, 89-96.

De la Rosa, D., Mayol, F., Moreno, J. A., Bonson, T., \& Lozano, S. (1999). An expert system/neural network model (ImpelERO) for evaluating agricultural soil erosion in Andalucia region. Agriculture, Ecosystems \& Environment, 73, 211-226. 
De la Rosa, D., Moreno, J. A., Mayol, F., \& Bonson, T. (2000). Assessment of soil erosion vulnerability in western Europe and potential impact on crop productivity due to loss of soil depth using the ImpelERO model. Agriculture, Ecosystems \& Environment, 81, 179-190.

De la Rosa, D., Mayol, F., Moreno, F., Cabrera, F., Diaz-Pereira, E., \& Antoine, J. (2002). A multilingual soil profile database (SDBm Plus) as an essential part of land resources information systems. Environmental Modeling \& Software, 17, 721-730.

De la Rosa, D., \& Van Diepen, C. (2003). Qualitative and quantitative land evaluation. In W. Verheye (Ed.), 1.5 Land Use and Land Cover, Encyclopedia of Life Support System (EOLSS-UNESCO). Oxford: Eolss. Available at http://www.eolss.net.

De la Rosa, D., Mayol, F., Diaz-Pereira, E., Fernandez, M., \& De la Rosa, D., Jr. (2004). A land evaluation decision support system (MicroLEIS DSS) for agricultural soil protection. Environmental Modeling \& Software, 19, 929-942. Available at http://www.microleis.com.

Derpsch, R., \& Benites, J. (2003). Situation of conservation agriculture in the world. In: Proceedings of the Second World Congress on Conservation Agriculture: Producing in harmony with nature. Iguasu, Brasil/Rome: FAO.

Dexter, A. R., \& Bird, N. R. A. (2001). Methods for predicting the optimum and the range of soil water contents for tillage based on the water retention curve. Soil \& Tillage Research, 57, 203-212.

Dexter, A. R. (2004). Soil physical quality. Part I. Theory, effects of soil texture, density and organic matter, and effects on root growth. Geoderma, 120, 201-214.

Doran, J. W., \& Jones, A. J. (1996). Methods for assessing soil quality. SSSA Special Publication 49. Madison, WI: Soil Science Society of America.

Doran, J. W., Sarrantonio, M., \& Liebig, M. A. (1997). Soil health and sustainability. Advances in Agronomy, 56, 1-54.

EC. (2002). Towards a thematic strategy for soil protection. Communication from the EC to the European Parliament. COM 2002, 179 final. Available at http://europa.eu.int/scadplus/ printversion/en/lvb/128122.htm.

FAO. (1976). A framework for land evaluation. Soils Bulletin, 32. Rome: FAO.

FAO. (1978). Report on the Agro-ecological Zones Project. World Soil Resources Report, 48. Rome: FAO.

FAO-CSIC, (2003). The multilingual soil profile database SDBm Plus. Land and Water Digital Media Series, 23. Rome: FAO.

Gomez, J. A., Giraldez, J. V., Pastor, M., \& Fereres, E. (1999). Effects of tillage methods on soil physical properties, infiltration and yield in an olive orchard. Soil \& Tillage Research, 52, 167-175.

ICASA. (2006). International Consortium for Agricultural Systems Application. Available at http://www.icasa.net. (Retrieved on 20 February 2006)

Imeson, A., Arnoldussen, A., De la Rosa, D., Montanarella, L., Dorren, L., Curfs, M., Arnalds, O., \& Van Asselen, S. (2006). SCAPE: Soil conservation and protection in Europe. The way ahead. Luxembourg: CEE-JRC.

Karlen, D. L., Mausbach, M. J., Doran, J. W., Cline, R. G., Harris, R. F., \& Schuman, G. E. (1997). Soil quality: A concept, definition and framework for evaluation. Soil Science Society of America Journal, 61, 4-10.

Martinez-Raya, A. (2003). Evaluacion y control de la erosion hidrica en suelos agricolas en pendiente, en clima mediterraneao. In: R. Bienes \& M. J. Marques (Eds.), Perspectivas de la degradacion del suelo (pp. 109-122). I Simp. Nac. Ero. Sue., Madrid.

Moreno, F., Murillo, J. M., Pelegrin, F., \& Giron, I. F. (2006). Long-term impact of conservation tillage on stratification ratio of soil organic carbon and loss of total and active CaCO3. Soil \& Tillage Research, 85, 86-93.

Moscatelli, G., \& Sobral, R. (2005). Avances en la selección de indicadores de calidad para las series de suelos representativas de la region Pampeana, Argentina. Buenos Aires: INTA. Available at http:// www.inta.gov.ar/mjuarez.

Nortcliff, S., (2002). Standardization of soil quality attributes. Agriculture, Ecosystems \& Environment, 88, 161-168.

Oxley, T., McIntosh, B. S., Winder, N., Mulligan, M., \& Engelen, G. (2004). Integrated modelling and decision support tools: A Mediterranean example. Environmental Modeling \& Software, 19, 999-1010. 
Pachepsky, Y., \& Rawls, W. J. (2004). Development of pedotransfer functions in soil hydrology. Development in Soil Science, Vol. 30. Amsterdam: Elsevier.

Quilchano, C., \& Marañon, T., (2002). Dehydrogenase activity in Mediterranean forest soils. Biological Fertility Soils, 35, 102-107.

Rossiter, D. (2003). Biophysical models in land evaluation. In W. Verheye (Ed.), 1.5 Land Use and Land Cover, Encyclopedia of Life Support System (EOLSS-UNESCO). Oxford: Eolss. Available at http://www.eolss.net.

Sojka, R. E., \& Upchurch, D: R. (1999). Reservations regarding the soil quality concept. Soil Science Society of America Journal, 63, 1039-1054.

Storie, R. E. (1933). An index for rating the agricultural value of soils. California Agricultural Experimental Station Bulletin, 556.

Thies, J. E. (2006). Measuring and assessing soil biological properties. In: N. Uphoff, A. Ball, E. Fernandes, H. Herren, O. Husson, M. Laing, Ch. Palm, J. Pretty, P. Sanchez, N. Sanginga \& J. Thies (Eds.), Biological approaches to sustainable soil systems (pp. 655-670). Boca Raton, FL: Taylor \& Francis/CRC Press.

Thysen, I. (2000). Agriculture in the information society. Journal of Agricultural Engineering Research, 76, 297-303.

Uphoff, N. (Ed.) (2002). Agro-ecological innovations: Increasing food production with participatory development. London: Earthscan.

Uphoff, N., Ball, A., Fernandes, E., Herren, H., Husson, O., Laing, M., Palm, Ch., Pretty, J., Sanchez, P., Sanginga, N., \& Thies, J. (Eds.) (2006). Biological approaches to sustainable soil systems. Boca Raton, FL: Taylor \& Francis/CRC Press.

USDA. (1961). Land capability classification. Agriculture handbook 210. Washington, DC: U.S. Government Printing Office.

USDA. (2006). Soil Quality Institute. Natural resources conservation service. Available at http:// soils.usda.gov/sqi/. (Retrieved on 20 February 2006.)

Van Lanen, H. A. J. (1991). Qualitative and quantitative physical land evaluation: An operational approach. Ph.D. thesis. Wageningen, The Netherlands: Wageningen Agricultural University. Verheye, W. (1988). The status of soil mapping and land evaluation for land use planning in the European Community. In: J. M. Boussard (Ed.), Agriculture: Socio-economic factors in land evaluation. Luxembourg: Office for Official Publications of the EU.

Wallace, A. (1994). Soil organic matter must be restored to near original levels. Communications in Soil Science \& Plant Analysis, 25, 29-35.

Warkentin, B. P. (1995). The changing concept of soil quality. Journal of Soil \& Water Conservation, 50, 226-228.

Wischmeier, W. H., \& Smith, D. D. (1965). Predicting rainfall erosion based from cropland east of the Rocky Mountains. Agriculture Handbook, 282. Washington, DC: U.S. Government Printing Office.

Wolfe, D. (2006). Approaches to monitoring soil systems. In N. Uphoff, A. Ball, E. Fernandes, H. Herren, O. Husson, M. Laing, Ch. Palm, J. Pretty, P. Sanchez, N. Sanginga \& J. Thies (Eds.), Biological approaches to sustainable soil systems (pp. 671-681). Boca Raton, FL: Taylor \& Francis/CRC Press.

Zalidis, G., Stamatiadis, S., Takavakoglou, V., Eskridge, K., \& Misopolinos, N. (2002). Impacts of agricultural practices on soil and water quality in the Mediterranean region and proposed assessment methodology. Agriculture, Ecosystems \& Environment, 88, 137-146. 